Volume 11

Issue 3 Global Approaches to Atrocity

Prevention: Theory, Practice, and the State of

Article 4 the Field

\title{
Global Approaches to Atrocity Prevention: Introduction to the Special Issue
}

James P. Finkel

George Mason University

Follow this and additional works at: https://digitalcommons.usf.edu/gsp

\section{Recommended Citation}

Finkel, James P. (2018) "Global Approaches to Atrocity Prevention: Introduction to the Special Issue," Genocide Studies and Prevention: An International Journal: Vol. 11: Iss. 3: 3-5.

DOI:

http://doi.org/10.5038/1911-9933.11.3.1589

Available at: https://digitalcommons.usf.edu/gsp/vol11/iss3/4

This Front Matter is brought to you for free and open access by the Open Access Journals at Digital Commons @ University of South Florida. It has been accepted for inclusion in Genocide Studies and Prevention: An International Journal by an authorized editor of Digital Commons @ University of South Florida. For more information, please contact digitalcommons@usf.edu. 


\section{Global Approaches to Atrocity Prevention: Introduction to the Special Issue}

Most observers who follow US human rights policy and atrocity prevention issues and recall the fate of Washington's first effort to systematically foresee and prevent atrocities - the second Clinton Administration's Interagency Atrocity Prevention Group led by former Ambassador-at-Large For War Crimes David Scheffer-probably expected the incoming Trump Administration to quickly dismantle the Obama era Atrocity Prevention Board and its subordinate units and procedures. Instead, despite the tumult of the Trump Administration's first year in office, an Atrocity Prevention Board has been reconstituted under the auspices of the National Security Council's International Organizations and Alliances directorate. The working level Sub-APB has continued to meet, staffed by a remarkable cadre of civil servants who are determined to ensure that the hard-learned lessons about what works are not lost, and who are also willing to reconsider approaches that have proved less promising or simply haven't worked. To their credit, they seem to be giving considerable thought to seeking ways to bridge the traditional "regional-functional" divide that has frequently weakened Washington's efforts on these questions. ${ }^{1}$ They also appear to be making a conscious effort to deepen the dialogue on atrocity prevention with key like-minded states and international organizations while simultaneously robustly engaging civil society. None of this is a one-time effort. It requires constant attention, and maintaining momentum is challenging due to frequent turnover of key staff, resource issues, and sudden shifts of policy decided at much higher levels of authority.

Meanwhile, as the essays that follow illustrate, atrocity prevention continues to attract attention from a diverse range of scholars and practitioners, both in the United States and abroad. Samantha Capicotto and Rob Scharf's article, "National Mechanisms for the Prevention of Atrocity Crimes," underscores the broad range of approaches to atrocity prevention currently being explored by different states, particularly in the global south, and the important role that local civil society is playing. It is hard to read their essay and avoid concluding that, while the mechanisms they discuss all have their individual challenges, the National Mechanisms are generating some of the most creative thinking about atrocity prevention that can be found anywhere.

Two of the issue's articles explore the structures and evolution of atrocity prevention policy in key like-minded countries, Switzerland and Germany. Giulia Persoz in her "Neutrality: A Tool or a Limit for Preventing Mass Atrocity Crimes and Genocide? The Case of Switzerland" traces the development of Switzerland's approach and Bern's efforts to be pro-active, while simultaneously continuing to pursue its traditional neutrality. Persoz underscores Swiss creativity and its support for various regional atrocity prevention forums, which in 2013 gave rise to a new international network, the Global Action Against Mass Atrocity Crimes, or GAAMAC. Persoz describes GAAMAC as a "platform to exchange best practices" and for helping build state capacities to develop and implement national preventive strategies. Switzerland chairs the network's Steering Committee.

Sarah Brockmeier and Philipp Rotman in "Germany's Politics and Bureaucracy for Preventing Atrocities" set out to introduce us to "the political context and recent history of Germany's institutional setup for atrocity prevention." They recount the implications of Germany's lack of a strong NGO community focused on atrocity prevention and note that "most of the prominent or semi-prominent politicians who do support a stronger German leadership role on atrocity prevention prefer to do so quietly, rather than championing the issue in public and risking to alienate voters." Individual studies of various countries' approaches to atrocity prevention have been few and far between. Hopefully, journal readers will take up the challenge in the months ahead to undertake similar research on other key countries including the UK, France, the Nordics, etc.

\footnotetext{
${ }^{1}$ See James P. Finkel, Atrocity Prevention At The Crossroads: Assessing The President's Atrocity Prevention Board After Two Years (Washington, DC: United States Holocaust Memorial Museum Center for the Prevention of Genocide, 2014); James P. Finkel, "Moving Beyond The Crossroads: Strengthening the Atrocity Prevention Board," Genocide Studies and Prevention: An International Journal, 9, no. 2 (2015), 138-147.
} 
Persoz's and Brockmeier and Rotman's articles both touch on resources and coordination as key challenges. Ed Luck, in his "Why the United Nations Underperforms at Preventing Mass Atrocities" and Ekkehard Strauss in "The UN Secretary General's Human Rights Up Front Initiative and the Prevention of Genocide: Impact, Potential, Limitations" highlight those issues as well. Luck insists that many of the UN's shortcomings arise from conceptual misunderstandings and institutional dysfunction along with capacity deficits. He also notes that the UN's emphasis on "maintaining impartiality and presence, humanitarian space and access may (sometimes) entail prioritizing the cultivation of good relations with the very regimes that may be committing or planning to commit... atrocities against their populations." He concludes with an important reminder that we are still very early in the process of learning how to curb atrocities.

In one of the most far-reaching looks at the UN's Human Rights Up Front Initiative to date, Strauss traces the evolution of UN thinking about various failures to deal effectively with atrocities, touching on Bosnia and Rwanda and more recently the Sri Lanka Panel's report on UN missteps. He characterizes the Human Rights Up Front Initiative as an internal UN action plan aimed at introducing "a cultural change within the UN, an operational change to bring the three pillars of the UN Charter (i.e. development, peace, and security, human rights) closer together, and a change to UN engagement with its member states." Strauss stresses that the Initiative is primarily a prevention tool that "aims to strengthen the link between early-warning and early-action." It is based on "a general recognition that human rights violations" can be "an early indicator of a deteriorating situation and that field presences can observe changing events and discuss them with their counterparts on the ground." To my knowledge, human rights has not heretofore figured prominently in most of the mainstream quantitative modeling efforts that aim to rank countries in terms of atrocity risk. Intuitively, this has never made sense to me. Regardless of whether the issue has been a data problem or a modeling issue, I suspect Strauss would agree that finding better ways to systematically and more dynamically integrate human rights information into our efforts at early warning of mass atrocities should yield important returns.

David Frank in his "The Reduction of Mass Atrocity Crimes in East Asia: The Evolving Norms of ASEAN's Prevention Mechanisms" and Matthew Levinger in "Forging Consensus For Atrocity Prevention, Assessing the Record of the OSCE" shed renewed light on the value and importance of norms at a time when so many of what have long been considered established rules of international relations are being cast in doubt. While highlighting Myanmar's treatment of its Rohingya population as a bright red exception, Frank notes the dramatic reduction in the incidence of mass atrocity crimes in East Asia over the past forty years. He argues that some of the change can be attributed to such "structural developments" as a decrease in the use of mass atrocities as a tool of war, rising incomes, and the spread of democracy, but his main focus is on the impact of the global community's development of new norms like the Responsibility to Protect (R2P) and their surprisingly rapid adoption by ASEAN and its member states. Matthew Levinger's essay on the Organization for Security and Co-operation in Europe (OSCE) provides something of a more cautionary tale in comparison to Frank's ASEAN piece. Levinger traces the evolution of the CSCE to what is now the OSCE along with its rules and institutions. He rightly lauds the accomplishments attributable to the generally quiet efforts of parts of the organization like the office of the High Commissioner on National Minorities (HCNM), but notes the impact that the evolution of NATO and the EU, and most importantly the strained relations between Russia and the US, have had on the OSCE's ability to play the type of role that originally was envisaged. He concludes that for OSCE to get back on track and "play a more robust role in enhancing human security in Eurasia," the organization will need to find a way to begin "rebuilding the normative consensus between its Eastern and Western participating states."

Finally, in their essay entitled "Improving Intervention Decisions To Prevent Genocide: Less Muddle, More Structure," decision scientists Robin Gregory, Michael Harstone, and Paul Slovic draw on multi-disciplinary research in decision analysis and psychology to offer "a general approach to assessing genocide prevention decisions" that they believe could provide decision makers with insight into how to construct more defensible intervention policies, linking proposed actions to national values in a manner that is both consistent and efficient. The authors readily concede that no decision-aiding framework can or should "make" the tough choices required of 
the US (or any other) government with respect to interventions intended to reduce the risk of genocide or other mass atrocities. But they argue (and persuasively, in my view) that adoption of a clear decision-aiding framework can improve the quality and extent of those deliberations. Surely, with so many lives potentially at risk, more systematic and thoughtful deliberations are called for.

My thanks to the articles' authors and the Journal's editorial board for making this special issue possible.

James P. Finkel

\section{Bibliography}

Finkel, James P. Atrocity Prevention at the Crossroads: Assessing the President's Atrocity Prevention Board After Two Years. Washington, DC: United States Holocaust Memorial Museum Center for the Prevention of Genocide, 2014.

"Moving Beyond the Crossroads: Strengthening the Atrocity Prevention Board." Genocide Studies and Prevention: An International Journal, 9, no. 2 (2015): 138-147. 